\title{
Kiégés és reziliencia (rugalmas ellenállás) a magyarországi orvosok körében
}

\author{
Győrffy Zsuzsa dr. \\ Semmelweis Egyetem, Általános Orvostudományi Kar, Magatartástudományi Intézet, Budapest
}

\begin{abstract}
Bevezetés: A gyógyítók kiégése mind a hazai, mind a nemzetközi kutatásokban kiemelt jelentőséggel bír. Célkitüzés: A 2017-ben folytatott reprezentatív, hazai orvoskutatás $(\mathrm{n}=5013)$ alapján bemutatni a kiégésmutatók alakulását, valamint e mutatók és a munkavégzés körülményei közötti összefüggéseket. Célul tűzzük ki továbbá a 2013. évi orvoskutatás eredményeivel való összevetést, valamint a kiégés és a reziliencia potenciális kapcsolatának vizsgálatát.

Módszer: Online, kvantitatív felmérés eredményeinek deskriptív és többváltozós elemzése. Logisztikus regressziós analízis segítségével vizsgáltuk meg a kiégés egyes dimenzióinak, valamint a rezilienciának a kapcsolatát.

Eredmények: A 2013. évi adatokkal való összevetésben az emocionális kimerülés és a teljesítményvesztés közepes és magas aránya megközelítóleg hasonlóan alakult ( $49 \%$ versus $49,9 \%$, illetve $65,1 \%$ versus $68,9 \%$ ). A deperszonalizáció esetében a 2013. évi adatokhoz képest (49\%) csökkenést tapasztaltunk (40,2\%). A fekvőbeteg-ellátásban dolgozók, a több munkahelyen helytállók és a rendszeresen ügyelők körében magasabb a kiégés. Többváltozós elemzésünk megmutatta, hogy a reziliencia hiánya fontos előrejelzője az emocionális kimerülésnek, a deperszonalizációnak és a teljesítménycsökkenésnek.

Következtetés: Eredményeink azt mutatják, hogy a kiégés alakulásában és visszaszorításában a belső erőforrásoknak, a rugalmas megküzdésnek és a rezilienciának kulcsszerepe van.
\end{abstract}

Orv Hetil. 2018; 160(3): 112-119.

Kulcsszavak: kiégés, orvosok, munkamegterhelés, reziliencia

\section{Burnout and resilience among Hungarian physicians}

Introduction: The burnout of healthcare workers is of outstanding significance in both national and international studies.

Aim: Based on a representative, national physician survey $(\mathrm{n}=5013)$, the aim of this study was to describe burnout indicators and the correspondence between them and working conditions. Moreover, we were aiming to compare the results with our 2013 physician survey and to analyze the potential relationship between burnout and resilience. Method: We analyzed the results of the online quantitative survey with multiple variables descriptively. The connection between the respective dimensions of burnout and resilience was studied with logistic regression.

Results: In comparison with data from 2013, the medium and high level proportions of depersonalization and personal accomplishment were similar ( $49 \%$ versus $49.9 \%$ and $65.1 \%$ versus $68.9 \%)$. Since 2013 (49\%), we experienced a decrease in depersonalization $(40.2 \%)$. Those working in in-patient care, at multiple workplaces and shift hours regularly have a higher chance of burnout. Our multivariable analysis has shown that the lack of resilience is an important predictor for the medium and high levels of emotional exhaustion, depersonalization and personal accomplishment.

Conclusion: Our results have shown that internal resources, coping strategies and resilience play a key role in burnout and its decrease.

Keywords: burnout, physicians, workload, resilience

Győrffy Zs. [Burnout and resilience among Hungarian physicians]. Orv Hetil. 2018; 160(3): 112-119.

(Beérkezett: 2018. július 22.; elfogadva: 2018. szeptember 7.) 


\section{Rövidítések}

DSM-V = Diagnostic and Statistical Manual of Mental Disorders, 5 th Edition; gyed = gyermekgondozási dij; gyes $=$ gyer mekgondozási segély; ICD = (International Classification of Diseases) Betegségek Nemzetközi Osztályozása; KSH = Központi Statisztikai Hivatal; MBI = (Maslach Burnout Inventory $)$ Maslach Kiégés Leltár; MOK = Magyar Orvosi Kamara; SD = standard deviáció; TUKEB = Tudományos és Kutatásetikai Bizottság; WHO = (World Health Organization) Egészségügyi Világszervezet

A gyógyítók kiégésének kutatása talán az utóbbi évtizedek egyik legdinamikusabban fejlődő területe. Az utóbbi évtizedben a legnagyobb orvosi témájú adatbázisokban (PubMed, Scopus) tízezres nagyságrendben láttak napvilágot a kiégéssel kapcsolatos tudományos publikációk. Az Orvosi Hetilap hasábjain több ízben jelentettünk meg közleményt, melyekben a hazai gyógyítók kiégésének különböző aspektusait igyekeztünk körüljárni [1-3].

A kiégés testi, lelki és mentális kimerülés, amely krónikus stresszhelyzetek, nagy emocionális megterhelés következtében alakul ki [4]. Maslach a kiégés három meghatározó komponensét tárta fel: az érzelmi kimerültséget, a deperszonalizációt (cinizmust) és a teljesítménycsökkenés dimenzióját [5]. A kiégés tünetegyüttese máig nem része a pszichiátriai diagnózisok körének (a DSM-V-nek vagy az ICD-10-nek), azonban számos kísérlet történt a depressziótól és a krónikusfáradtság-szindrómától való elhatárolásra. A kiégést (burnoutot) ugyanis alapvetően külső hatások befolyásolják (például munkakörnyezet, munkamegterhelés, munkavégzés feletti kontroll), és fö prediktora a „másokkal” (betegekkel, kliensekkel) való intenzív érzelmi és fizikai kapcsolat, illetve a mindezekből fakadó interperszonális stressz [6].

A kiégés mind a gyógyítók, mind betegeik egészségére, jóllétére hatással bír. Számtalan vizsgálat mutatta ki a kiégés szomatikus következményeit, és egyre több vizsgálat fókuszába kerül a kiégésnek a betegellátásra való negatív hatása [7]. A potenciális következmények között egyre nagyobb hangsúllyal jelennek meg a múhibákra és a szövődmények előfordulására vonatkozó vizsgálatok, amelyek mindegyike szoros összefüggést mutat ki a kiégett gyógyító és a komplikációk előfordulása között [8]. A kiégéssel összefüggésben megjelenik a „diszruptív orvos" fogalma is, aki nem megfelelő kommunikációjával, korlátozott információátadásával és diszfunkcionális csapatmunkájával veszélyezteti a biztonságos betegellátást $[9,10]$.

A fentiekkel párhuzamosan megfigyelhető, hogy a gyógyítói jóllétre vonatkozó vizsgálatok nemzetközi trendjeiben egyre gyakrabban jelenik meg az a törekvés, hogy ne csupán a problémák és a patomechanizmusok hangsúlyozása álljon a középpontban, hanem annak leírása is, hogy milyen erőforrásokkal, megküzdési módokkal, stresszkezelési stratégiákkal maradhatnak egészségesek és kiegyensúlyozottak az orvosok [11].
Napjaink orvoskutatásainak körében is egyre hangsúlyosabban jelenik meg a salutogeneticus megközelítés [12]. Az Antonovsky nevéhez köthető elmélet központi eleme a koherenciaérzés, amely „a személynek saját magával és a világgal szemben tanuisitott és átélt beállitódása, annak biztonsága, hogy a minket körülvevő és a bennünk megnyilvánuló világ kiszámitható, és az események nagy valószinu"séggel befolyásolbatók”[13].

E terület vizsgálatában egyre növekszik azon kutatások száma, amelyek a gyógyítói rezilienciával kapcsolatosak. A rezilienciát rugalmas alkalmazkodóképességként definiálhatjuk, amely sikeres adaptációt jelent a kisebb stresszekkel és a nagyobb traumákkal szemben. Jelenti továbbá azt a képességünket, hogy gyorsan vissza tudjuk nyerni eredeti állapotunkat nehéz élethelyzetek átélése után [14]. Fontos ugyanakkor hangsúlyozni, hogy a reziliencia fogalma meglehetősen komplex, értelmezése, operacionalizálása még mindig az intenzív tudományos diskurzus része [15]. Az 1970-es évektől kezdődően indult meg e terület kutatása, elsősorban olyan longitudinális perspektívájú vizsgálatokra fókuszálva, amelyek a nehéz gyermekkori körülmények versus sikeres felnőttkor összefüggéseit igyekeztek feltárni. A kiégéskutatásokhoz hasonlóan először a személyiségtényezők feltárására irányultak a vizsgálatok, majd egyre inkább előtérbe kerültek azok az elképzelések, amelyek a folyamat komplexitását hangsúlyozzák. A jelenlegi álláspont szerint a reziliencia multidimenzionális jelenség, amelyben a külső és belső faktorok dinamikus interakciója figyelhetô meg [16].

Jelen vizsgálatunk célkitúzései a következőképpen határozhatók meg:

1. A 2017. évi reprezentatív orvoskutatás kiégésmutatóinak bemutatása és az adatok összevetése a 2013. évi, ugyancsak reprezentatív vizsgálat eredményeivel.

2. A magyarországi orvosok kiégésmutatóinak leírásán túl célul tûztük ki, hogy a kiégésmutatók és a munkavégzés körülményeit érintő legmeghatározóbb aspektusok (munkaórák, ügyeleti munkavégzés, több munkahelyen való helytállás) összefüggéseit bemutassuk.

3. Elsőként szeretnénk - reprezentatív adatok segítségével - leírni a hazai orvostársadalom rezilienciájának jellemzőit.

4. Egy- és többváltozós elemzés segítségével kívánjuk feltárni a kiégés és a reziliencia közötti lehetséges öszszefüggést, összefüggéseket.

\section{Minta és módszer}

Kvantitatív, online felmérésünk a magyarországi orvosokra (általános orvosokra és fogorvosokra) összpontosított. Az orvosi minta esetében alapsokaságnak a Magyar Orvosi Kamara adatbázisában megtalálható, érvényes email-címmel rendelkező orvosokat tekintettük $(\mathrm{n}=$ 40 921). Vizsgálatunk 2017. április 24. és október 5. között folyt, az anonim, önkitöltős kérdőív linkjének kiküldése után két emlékeztető levél ösztönzésével. A vizs- 
gálatot a MOK és a Semmelweis Egyetem Etikai Bizottságának engedélyével folytattuk le (a TUKEB-engedély száma: 284/2016).

A válaszadási arány $12,27 \%$-os volt $(\mathrm{n}=5024)$. Ez a válaszadási arány az online, orvosok körében folytatott kutatások részvételi hajlandósági adataihoz viszonyítva megfelelő [17].

A kutatás lezárása után az adatokon elvégeztük a szükséges adattisztítást. A felmérés adatain nem, kor és szak (orvos, fogorvos) szerinti korrekciós súlyozást végeztünk, az alapsokasági adatokat a Magyar Orvosi Kamara tagsági adatai szolgáltatták. A súlyozási eljárás után a minta elemszáma 5013 fó.

Jelen elemzésünkben csak az általános orvosokat $(\mathrm{n}=$ 4204) vizsgáljuk, és minden esetben csak az érvényes válaszok adatait elemezzük.

\section{A kutatás témakörei}

A vizsgálat fó témakörei a következők voltak:

1. Demográfiai adatok (életkor, lakóhely, családi állapot, gyerekszám).

2. Munkahelyre vonatkozó adatok (munkahelytípus, jelenlegi szak, szakvizsgák száma, ügyeletek száma, mellékállások, magánpraxisok, előző munkahelyek, a munkaidő mennyisége).

3. Az egészségi állapotra vonatkozó adatok (39 tételből álló betegséglista).

4. Pszichológiai tényezők (kiégés, reziliencia, WHO-jóllét, alvászavarok).

5. A munkával és munkavégzéssel kapcsolatos attitűdök.

Jelen tanulmányunk fókuszában a munkavégzéssel, a kiégéssel és a rezilienciával kapcsolatos adatok elemzése áll.

\section{Méröeszközök}

A szociodemográfiai adatok elemzésekor az életkort 4 kategóriában vizsgáltuk: 35 éves kor alatt, 36-50 éves életkor között, 51-65 éves életkor között és 65 év felett. Vizsgáltuk a partnerkapcsolat meglétét és a megszületett gyerekek számát. Kétkategóriás változóként vizsgáltuk az orvos házastárs/partner meglétét („Partnere orvos/ fogorvos?" - Igen/Nem). Jelen elemzésünkben a munkahelytípust az alapellátási, szakellátási, fekvőbeteg-ellátási és egyéb (magánegészségügyi intézmény, nonprofit szféra, oktatás stb.) dimenziókban tekintettük át. Vizsgáltuk a munkahelyek számát (folyamatos változóként), az ügyeleti munkavégzést, valamint a munkaidő alakulását.

A kiégés mérésére a Maslach Burnout Inventoryt (MBI) használtuk $[18,19]$. Az MBI egy 22 tételből álló kérdőív, mely a kiégést három dimenzióban méri (emocionális kimerülés, deperszonalizáció és teljesítményvesztés). A résztvevők hétfokozatú Likert-skálán (0-tól 6-ig terjedően) jelzik, hogy egyes, a munkájukkal kapcsolatos érzéseiket milyen gyakran észlelik.
Az MBI 22 állítást tartalmaz, amelyben kilenc állítás vonatkozik az emocionális kimerülésre („kifacsart vagyok a munkanap végén”; „már akkor is fáradt vagyok, amikor reggel felkelek, és egy új munkanappal nézek szembe”; „úgy érzem, mintha utolsó erőtartalékaimat élném fel”; stb.). A deperszonalizációt öt állítás méri („úgy érzem, hogy az embereket személytelen tárgyakként kezelem”; „úgy érzem, hogy munkám érzelmileg megkeményít”; „valójában nem érdekelnek azok az emberek, akikkel foglalkoznom kell”; stb.). A teljesítményvesztést nyolc állítás méri ( „úgy érzem, hogy munkámon keresztül pozitívan tudom befolyásolni más emberek életét”; "hatékonyan tudok foglalkozni a hozzám forduló emberek problémáival"; "tele vagyok energiával”, stb.).

Az egyes faktorokon belüli összpontszám harmadolásával három osztályt alakítottak ki a mérőeszköz kidolgozói (1. alacsony, 2. közepes, 3. magas). Az orvosok körében a magas fokú kiégést a következő értékek jelzik: emocionális kimerülés: >27 pont; deperszonalizáció: >10 pont; teljesítménycsökkenés: <33 pont. Vizsgálatunkban az emocionális kimerülés Cronbach-alfa-értéke: 0,894, a deperszonalizáció Cronbach-alfa-értéke: 0,815, a teljesítményvesztés Cronbach-alfa-értéke pedig 0,810.

A reziliencia mérésére a 10 tételes Connor-Davidson Reziliencia Skála hazai, validált változatát használtuk. A válaszadók ötfokú Likert-skálán (0 - egyáltalán nem igaz, 4 - szinte mindig igaz) értékelik az egyes tételeket. A kérdőív az alábbi tételeket tartalmazza:

1. Képes vagyok arra, hogy alkalmazkodjak a változásokhoz.

2. A stresszel való megküzdés megerősít.

3. Mindig a legnagyobb eróbedobással cselekszem, mindegy, hogy miről van szó.

4. Amikor a dolgok reménytelennek tünnek, akkor sem adom fel.

5. Tisztán gondolkodom és koncentrálok, amikor nyomás alatt vagyok.

6. Erős emberként gondolok magamra.

7. A megérzéseim alapján kell cselekednem.

8. Nagyon céltudatos vagyok.

9. Úgy érzem, én irányítom az életemet.

10. Dolgozom azért, hogy elérjem a céljaimat $[20,21]$.

A nemzetközi ajánlásoknak megfelelően a kérdőív itemjeinek összegzése után átlagpontszámot számítottunk, majd az eredmények alapján „átlag alatti” és „átlag feletti" reziliencia-pontszámokat alakítottunk ki [20]. A reziliencia-kérdőív Cronbach-alfa-értéke vizsgálatunkban: 0,870 .

\section{Statisztikai módszerek}

A kvantitatív vizsgálat során deskriptív elemzést végeztünk, amelynek során gyakoriságokat, átlagokat és százalékos megoszlást vizsgáltunk. A kiégést és különböző korrelátumait (szociodemográfiai, munkával kapcsolatos változók, valamint a reziliencia) egyváltozós elemzés - 
Pearson-féle khi-négyzet $\left(\chi^{2}\right)$-próba; szignifikanciaszint: p $<0,05$ - segítségével hasonlítottuk össze. Többváltozós analízisünkben bináris logisztikus regressziós modellt alkalmaztunk. Logisztikus regressziós elemzés segítségével vizsgáltuk meg a kiégés egyes dimenzióinak, valamint a rezilienciának a kapcsolatát. A többváltozós elemzés esetében a függó változó a kiégés kétkategóriás (kiégés alacsony/közepes, illetve magas) változója volt. A kontrollváltozók a következők voltak: nem (férfi/nő), kor (4 kategóriában: 35 éves kor alatt, 36-50 év között, 51-65 év között és 65 év felett), munkahelytípus (4 kategóriában: fekvőbeteg-ellátás, szakellátás, alapellátás, egyéb), a munkahelyek száma (folytonos változó), ügyeleti munkavégzés (igen/nem), gyerekszám (van/nincs gyermeke). A modellbe utolsóként léptettük be a reziliencia kétkategóriás változóját (átlag alatti/átlag feletti reziliencia).

A modellben a függő változót befolyásoló független változókat kizárásos lépésenkénti regresszióval (backward stepwise logistic regression) választottuk ki. Az egyes változókhoz tartozó regressziós koefficiensek szignifikanciáját a Wald-próba p-értékével jellemeztük, és a $\mathrm{p}<0,10$ változókat tartottuk bent a végső modellben.

A jelen tanulmányban a súlyozás utáni minta általános orvosokra vonatkozó válaszait elemezzük ( $n=4204)$, és minden esetben az érvényes válaszok arányait vizsgáljuk. $\mathrm{Az}$ adatok statisztikai elemzése az SPSS 22.0 programmal (IBM, Armonk, NY, Amerikai Egyesült Államok) történt.

\section{Eredmények}

\section{A szociodemográfiai mutatók alakulása}

A vizsgálatban 1968 fó a férfiak és 2242 a nők száma, vagyis a férfiak aránya 46,6 százalék, a nőké 53,4 százalék. A válaszadók átlagéletkora 53,86 év. A minta kormegoszlása az 1 ábrán látható.

A válaszadók több mint kétharmada házas $(63,6 \%)$, a kapcsolatban élők aránya 16\%, 7,5\%-uk elvált, 7,9\%-uk egyedül él, és 5\%-uk özvegy.

Mintánkban 27,7\%-nyian vannak azok, akiknek a partnere orvos. A fogorvos vagy gyógyszerész partnerek aránya 1,3 , illetve $1,9 \%$, és több, mint $8,9 \%$-uk partnere egészségügyi szakdolgozó. Elmondható tehát, hogy a válaszadók közel 40\%-ának párja az egészségügy területén dolgozik. A megkérdezettek 39,2\%-ának 2 gyermeke van, $21,4 \%$ a gyermektelenek és $17,9 \%$ az egygyermekesek aránya; 15,2, illetve 4,7\%-uknak van 3, illetve 4 gyermeke.

A felmérésben részt vevő, betegellátásban dolgozók közel fele, 49,8\%-uk szakorvosként dolgozik, 13,9\%-uk rezidens, 15,8\%-uk nyugdíjas orvosként dolgozik. További jelentős létszámú csoport (15,4\%-os aránnyal) a vállalkozó orvosoké; 2,3 , illetve $0,5 \%$ az egyetemi oktatók, illetve kutatók aránya, 0,9\%-uk pedig gyesen vagy gyeden van.

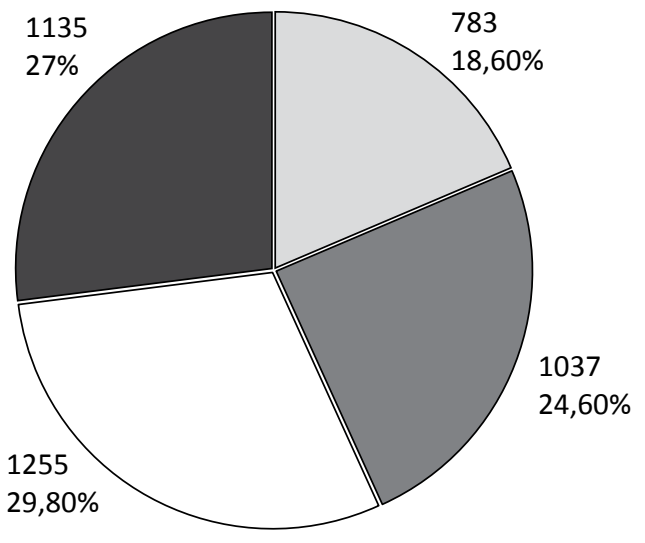

$\square 35$ éves kor alatt

$\square 36-50$ éves

$\square$ 51-65 éves

$65+$ éves

1. ábra

| A minta kormegoszlása (elemszám, \%)

A munkahelytípust tekintve a válaszadók 43,9\%-a dolgozik a fekvőbeteg-ellátásban, 11,9\%-uk a járóbetegszakellátásban, 23,7\%-uk az alapellátásban és 20,5\%-uk egyéb munkahelyeken (civil szervezet, államigazgatás, magánszféra). A megkérdezett orvosok 4,6\%-ának nincs állása, 50,4\%-nyian egy munkahelyen dolgoznak, több mint egynegyedük $(26,7 \%) 2,12,8 \%$-uk 3 munkahelyen dolgozik. A minta 4,8\%-a pedig egy időben négy vagy több helyen dolgozik. Válaszadóink állásainak száma átlagosan 2,67.

A megkérdezettek átlagosan 1,38 szakvizsgával rendelkeznek. A legtöbben (38,7\%) l szakvizsgával, 31,7\% 2, közel 10,5\% 3 szakvizsgával rendelkezik. A válaszadók 16\%-ának nincs szakvizsgája. Az 1. táblázat mutatja, hogy milyen szakvizsgát szereztek először.

Az ügyeleti beosztást feltérképező kérdésünkre a válaszadók közel fele $(48,1 \%)$ válaszolta, hogy nem ügyel, közel 29,7\%-uk ügyel, majdnem 13,4\%-nyian ügyelet és készenlét formájában ügyelnek, $7,1 \%$ a készenléti beosztásban dolgozók aránya, 4,2\% dolgozik múszakos munkarendben (a szintén több válasz megjelölését lehetővé tevő kérdőív alapján). A mintában szereplő orvosok 39,9\%-a számára kötelező az ügyeleti munka vállalása.

Arra is rákérdeztünk, hogy az orvosok hetente átlagosan mennyi időt dolgoznak fóállásban, másodállásban, ügyeletben, illetve mennyi időt töltenek munkához kapcsolódó utazással. Orvos válaszadóink átlagosan heti 35,71 órát fóállásban, 11,93 órát másodállásban dolgoznak, 13,69 órát ügyelnek, és 5,1 órát töltenek munkához kapcsolódó utazással, ingázással.

\section{A kiégés és korrelátumainak alakulása az orvosi mintában}

Válaszadóink körében az érzelmi kimerülés alskálájának átlagpontszáma 19,48 (SD = 12,77), a deperszonalizációs alskáláé $5,9(\mathrm{SD}=6,23)$, míg a teljesítményvesztési alskála átlagpontszáma 33,73 $(\mathrm{SD}=9,29)$ pont körül 
1. táblázat

| A leggyakrabban előforduló szakvizsgák megoszlása

\begin{tabular}{|c|c|c|}
\hline & Elemszám & Százalék (\%) \\
\hline Aneszteziológia és intenzív terápia & 207 & 5,3 \\
\hline Belgyógyászat & 687 & 17,4 \\
\hline Bőrgyógyászat & 64 & 1,6 \\
\hline Csecsemő- és gyermekgyógyászat & 427 & 10,8 \\
\hline Fül-orr-gége gyógyászat & 85 & 2,2 \\
\hline Háziorvostan & 371 & 9,4 \\
\hline Honvédorvostan, katasztrófa-orvostan & 4 & 0,1 \\
\hline Idegsebészet & 1 & 0,0 \\
\hline Igazságügyi orvostan & 11 & 0,3 \\
\hline Infektológia & 17 & 0,4 \\
\hline Kardiológia & 11 & 0,3 \\
\hline Konzerváló fogászat és fogpótlástan & 373 & 9,5 \\
\hline Megelőző orvostan és népegészségtan & 36 & 0,9 \\
\hline Neurológia & 112 & 2,8 \\
\hline Nukleáris medicina & 7 & 0,2 \\
\hline Ortopédia és traumatológia & 74 & 1,9 \\
\hline Orvosi laboratóriumi diagnosztika & 89 & 2,2 \\
\hline Orvosi mikrobiológia & 7 & 0,2 \\
\hline Oxiológia és sürgősségi orvostan & 33 & 0,8 \\
\hline Patológia & 70 & 1,8 \\
\hline Pszichiátria & 110 & 2,8 \\
\hline Radiológia & 112 & 2,8 \\
\hline Reumatológia & 63 & 1,6 \\
\hline Sebészet & 269 & 6,8 \\
\hline Szemészet & 96 & 2,4 \\
\hline Szülészet-nőgyógyászat & 213 & 5,4 \\
\hline Tüdőgyógyászat & 102 & 2,6 \\
\hline Urológia & 50 & 1,3 \\
\hline
\end{tabular}

alakult. Az érzelmi kimerülés alacsony övezetébe a válaszadók 47\%-a, közepes övezetébe a 29,2\%-uk, míg magas övezetébe a 23,2\%-uk tartozott. A deperszonalizáció esetében a minta $59,8 \%$-a tartozott az alacsony övezetbe, $22,1 \%$ a közepes, míg $18,1 \%$ a magas tartományba. A teljesítménycsökkenési alskálát végigtekintve megállapíthatjuk, hogy a válaszadók 30,3\%-a az alacsony övezetbe, $27,7 \%$-a a közepes és $42 \%$-a a magas övezetbe tartozott (2. táblázat).

A kiégés nemek szerinti különbségeit végigtekintve elmondható, hogy az emocionális kimerülés közepes és magas komponense szignifikánsan gyakrabban fordul elő a nóknél $(48,6 \%$ versus $41,9 \%, \mathrm{p}<0,001)$. A deperszonalizáció közepes és magas aránya a férfiaknál fordul elő gyakrabban: $45,3 \%$ versus $51,4 \%, \mathrm{p}<0,043$. A két nem között a teljesítményvesztés vonatkozásában nem találtunk jelentős különbséget ( $47,7 \%$ versus $51,3 \%)$.

A kiégés mindhárom dimenzióját áttekintve elmondható, hogy a fiatal orvosoknál - elsősorban a 35 évesnél fiatalabbaknál - igen magas értékek mutatkoznak (3. táblázat).

Ha adatainkat munkahelytípus szerint értelmezzük, látható, hogy a fekvőbeteg-ellátásban dolgozók a kiégés mindhárom dimenziójában jelentősen magasabb értéket mutatnak, mint a más munkahelytípusban dolgozók $(\mathrm{p}<0,001)$ (3. táblázat).

A kiégés különböző dimenzióit tekintve a munkahelyek száma meghatározó faktor. Az emocionális kimerülés $(39,3 \%$ versus $52,4 \%, \mathrm{p}<0,001)$ és a deperszonalizáció $(33,3 \%$ versus $41 \%, \mathrm{p}<0,020)$ is szignifikánsan nagyobb arányban jelenik meg a több munkahelyen helytállóknál. A teljesítménycsökkenés esetében nem találtunk szignifikáns különbséget a munkahelyek számával való összefüggésben (3. táblázat).

A munkahelyek számához hasonlóan az ügyeleti mun$\mathrm{ka}$ is jelentős összefüggést mutat a kiégéssel. Azok között, akiknek kötelező ügyeleti munkát vállalniuk, mind az emocionális kimerülés ( $42,6 \%$ versus $63,2 \%, \mathrm{p}<0,001)$, mind a deperszonalizáció $(36,4 \%$ versus $63,5 \%, \mathrm{p}<0,001)$, mind pedig a teljesítményvesztés $(66,1 \%$ versus $74,9 \%$, $\mathrm{p}<0,001)$ szignifikánsan nagyobb arányú. A rezidensek körében mind az emocionális kimerülés $(67,6 \%$ versus $48,3 \%, \mathrm{p}<0,001)$, mind a deperszonalizáció $(51,9 \%$ versus $41,2 \%, \mathrm{p}<0,001)$, mind pedig a teljesítményvesztés dimenziója $(80,1 \%$ versus $68 \%, \mathrm{p}<0,001)$ jelentősen nagyobb arányú a szakorvosokhoz képest.

A gyerekszám is befolyásolja a kiégés alakulását: a gyermektelenek a kiégés mindhárom dimenziójában szignifikánsan nagyobb arányban voltak jelen (3. táblá$z a t)$.

\section{A reziliencia alakulása a vizsgált mintában}

Vizsgált mintánkban a reziliencia átlagpontszáma 26,88 $(\mathrm{SD}=6,64)$. Átlag alatti reziliencia-pontszámmal a válaszadó orvosok 49,6\%-a (2068 fó) jellemezhető, míg átlag feletti értéket 50,2\% (2081 fó) mutatott.

Megvizsgáltuk a reziliencia lehetséges korrelátumait mind a demográfiai (nem, kor, családi állapot, gyerekszám), mind pedig a munkával kapcsolatos mutatókkal (munkahelytípus, a munkahelyek száma, ügyeleti munka végzése), ám egyetlen esetben sem találtunk szignifikáns kapcsolatot a fenti változók és a reziliencia között.

A kiégés és a rezilencia összefüggéseirôl elmondható, hogy az alacsonyabb reziliencia-pontszám mind az emocionális kimerülés $(60,9 \%$ versus $41,3 \%, \mathrm{p}<0,001)$, mind

2. táblázat |A kiégés három dimenziójának alakulása a vizsgált mintában

\begin{tabular}{lccc}
\hline & $\begin{array}{c}\text { Emocionális } \\
\text { kimerülés } \\
\%\end{array}$ & $\begin{array}{c}\text { Deperszonalizáció } \\
\%\end{array}$ & $\begin{array}{c}\text { Teljesítmény- } \\
\text { vesztés } \\
\%\end{array}$ \\
\hline Alacsony & 47 & 59,8 & 30,3 \\
Közepes & 29,2 & 22,1 & 27,7 \\
Magas & 23,2 & 18,1 & 42 \\
\hline
\end{tabular}


3. táblázat

A kiégés különböző korrelátumainak összefüggései

\begin{tabular}{|c|c|c|c|}
\hline & $\begin{array}{c}\text { Emocionális } \\
\text { kimerülés } \\
\text { közepes/magas } \\
\%(\mathrm{n})\end{array}$ & $\begin{array}{l}\text { Deperszonali- } \\
\text { záció közepes/ } \\
\text { magas } \\
\%(\mathrm{n})\end{array}$ & $\begin{array}{l}\text { Teljesítmény- } \\
\text { csökkenés } \\
\text { közepes/magas } \\
\%(\mathrm{n})\end{array}$ \\
\hline \multicolumn{4}{|l|}{ Kor } \\
\hline 35 éves kor alatt & $67,4 \%(522)$ & $61,7 \%(476)$ & $80,3 \%(621)$ \\
\hline 36-50 éves & $61,7 \%(634)$ & $48,5 \%(497)$ & $71,6 \%(736)$ \\
\hline 51-65 éves & $53,5 \%(666)$ & $37,5 \%(466)$ & $66,2 \%(824)$ \\
\hline $65+$ éves & $25,0 \%(258)$ & $18,6 \%(187)$ & $63,9 \%(661)$ \\
\hline \multicolumn{4}{|l|}{ Munkabelytipus } \\
\hline Fekvőbeteg-ellátás & $61,4 \%(1071)$ & $49,5 \%(861)$ & $75,8 \%(1325)$ \\
\hline Szakellátás & $45,5 \%(214)$ & $34,6 \%(160)$ & $66,4 \%(312)$ \\
\hline Alapellátás & $43,7 \%(411)$ & $32,8 \%(307)$ & $62,7 \%(589)$ \\
\hline Egyéb ellátás & $42,3 \%(338)$ & $33,0 \%(262)$ & $65,5 \%(521)$ \\
\hline \multicolumn{4}{|l|}{ Gyerekszám } \\
\hline 0 gyerek & $64,0 \%(548)$ & $56,2 \%(480)$ & $78,8 \%(674)$ \\
\hline 1 gyerek & $52,2 \%(361)$ & $38,5 \%(265)$ & $67,1 \%(465)$ \\
\hline 2 gyerek & $46,8 \%(718)$ & $34,7 \%(525)$ & $68,3 \%(1044)$ \\
\hline 3 vagy több gyerek & $45,3 \%(452)$ & $35,9 \%(356)$ & $65,7 \%(659)$ \\
\hline
\end{tabular}

a deperszonalizáció $(49,7 \%$ versus $31 \%, \mathrm{p}<0,001)$, mind pedig a teljesítménycsökkenés $(85,5 \%$ versus $55,2 \%$, $\mathrm{p}<0,001)$ esetében szignifikáns összefüggést mutatott a kiégés közepes és magas arányú előfordulásával.

\section{A reziliencia és a kiégés alakulása többváltozós modellben}

Többváltozós elemzésben is megvizsgáltuk az emocionális kimerülés, a deperszonalizáció és a teljesítménycsökkenés kapcsolatát a reziliencia alakulásával. A 'Statisztikai módszerek' részben ismertetett kontrollváltozók beléptetése után úgy találtuk, hogy a kiégés mindhárom dimenziójának esetében a reziliencia átlag alatti értéke fontos magyarázó tényezőnek bizonyult (a táblázatokban csak a modell szignifikáns elemeit mutatjuk be) (46. táblázat).

\section{Megbeszélés}

Vizsgálatunkban a hazai orvosok kiégésmutatóinak, azok háttértényezőinek, valamint a kiégés és a reziliencia kapcsolatának feltárását helyeztük a középpontba. Kutatási eredményeink alapján elmondható, hogy a 2013. évi adatokkal való összevetésben az emocionális kimerülés és a teljesítményvesztés közepes és magas aránya megközelítóleg hasonlóan alakult ( $49 \%$ versus $49,9 \%$, illetve $65,1 \%$ versus $68,9 \%$ ). A deperszonalizáció esetében a 2013. évi adatokhoz képest (49\%) csökkenést tapasztaltunk $(38,9 \%)$. A korábbi felmérés adataihoz hasonlóan alakul a kiégés egyes dimenzióinak nemek közötti megoszlása: a nők az emocionális kimerülés, a férfiak pedig a deperszonalizáció dimenziójában mutatnak többletet. A teljesítménycsökkenés komponense a nemek között nem mutat különbséget. Továbbra is jellemző, hogy a legfiatalabb orvosi korosztály (<35) és a rezidensek a legérintettebbek a kiégés minden aspektusát tekintve, azonban 2017-ben az is trendként rajzolódik ki, hogy a kiégés az életkori csoportok szerint csökken. Ezen adataink némileg ellentmondanak a nemzetközi tendenciáknak: az amerikai orvostársaság legfrissebb kiégésfelmérése sze-

4. táblázat $\mid$ Az emocionális kimerülés magyarázó tényezői többváltozós modellben $\left(\mathrm{R}^{2}=0,191\right)$

\begin{tabular}{|c|c|c|c|c|c|}
\hline \multirow[t]{2}{*}{ Kontrollváltozók } & \multirow[t]{2}{*}{ Wald } & \multirow[t]{2}{*}{ Sig. } & \multirow[t]{2}{*}{$\operatorname{Exp}(B)$} & \multicolumn{2}{|c|}{$\begin{array}{c}95 \% \mathrm{CI} \\
\text { for } \operatorname{EXP}(\mathrm{B})\end{array}$} \\
\hline & & & & Lower & Upper \\
\hline Kor (35 év alattiak) & 84,777 & 0,000 & 3,911 & 2,925 & 5,228 \\
\hline $\begin{array}{l}\text { Munkahelytípus } \\
\text { (fekvőbeteg-ellátás) }\end{array}$ & 17,982 & 0,000 & 1,491 & 1,210 & 1,837 \\
\hline $\begin{array}{l}\text { Ügyeleti munka } \\
\text { (igen) }\end{array}$ & 18,091 & 0,000 & 1,447 & 1,222 & 1,715 \\
\hline $\begin{array}{l}\text { Reziliencia (átlag } \\
\text { alatti pontszám) }\end{array}$ & 134,013 & 0,000 & 2,469 & 2,118 & 2,881 \\
\hline
\end{tabular}

$\mathrm{CI}=$ konfidenciaintervallum

5. táblázat |A deperszonalizáció magyarázó tényezői többváltozós modellben $\left(\mathrm{R}^{2}=0,204\right)$

\begin{tabular}{|c|c|c|c|c|c|}
\hline \multirow[t]{2}{*}{ Kontrollváltozók } & \multirow[t]{2}{*}{ Wald } & \multirow[t]{2}{*}{ Sig. } & \multirow[t]{2}{*}{$\operatorname{Exp}(B)$} & \multicolumn{2}{|c|}{$95 \%$ CI for $\operatorname{EXP}(B)$} \\
\hline & & & & Lower & Upper \\
\hline Férfiak & 33,606 & 0,000 & 1,580 & 1,353 & 1,844 \\
\hline $\begin{array}{l}\text { Kor (35 év } \\
\text { alattiak) }\end{array}$ & 136,252 & 0,000 & 6,109 & 4,503 & 8,279 \\
\hline $\begin{array}{l}\text { Ügyeleti munka } \\
\text { (igen) }\end{array}$ & 14,809 & 0,000 & 1,404 & 1,180 & 1,669 \\
\hline $\begin{array}{l}\text { Reziliencia (átlag } \\
\text { alatti pontszám) }\end{array}$ & 130,663 & 0,000 & 2,433 & 2,092 & 2,832 \\
\hline
\end{tabular}

$\mathrm{CI}=$ konfidenciaintervallum

6. táblázat |A teljesítménycsökkenés magyarázó tényezői többváltozós modellben $\left(\mathrm{R}^{2}=0,198\right)$

\begin{tabular}{lccccc}
\hline Kontrollváltozók & Wald & Sig. & $\operatorname{Exp}(\mathrm{B})$ & \multicolumn{2}{c}{$95 \%$ CI for EXP (B) } \\
\cline { 5 - 6 } & & & & Lower & Upper \\
\hline Férfiak & 10,503 & 0,001 & 1,310 & 1,112 & 1,542 \\
$\begin{array}{l}\text { Kor (35 év } \\
\text { alattiak) }\end{array}$ & 11,821 & 0,002 & 1,734 & 1,267 & 2,373 \\
$\begin{array}{l}\text { Fekvốbeteg- } \\
\text { ellátás }\end{array}$ & 5,315 & 0,021 & 1,303 & 1,040 & 1,631 \\
$\begin{array}{l}\text { Reziliencia (átlag } \\
\text { alatti pontszám) }\end{array}$ & 308,946 & 0,000 & 5,882 & 7,142 & 4,830 \\
\hline
\end{tabular}

$\mathrm{CI}=$ konfidenciaintervallum 
rint például a 45-55 éves korosztály messze kiemelkedik a kiégés magas arányát tekintve [22]. A kiégés munkával való összefüggéseiben nincs jelentős változás a korábbi felmérés adataihoz képest: a fekvőbeteg-ellátásban dolgozók, a több munkahelyen helytállók és a rendszeresen ügyelők körében magasabb a kiégés.

A rezilienciával kapcsolatos eredményeink a kutatásokban használt eltérő mérőeszközök miatt nehezen vethetők össze a nemzetközi trendekkel [23]. Vizsgálatunkban az átlag alatti és feletti mutatók közel azonos eloszlásúak, és a reziliencia nem mutat sem a szociodemográfiai, sem pedig a munkával kapcsolatos tényezőkkel szignifikáns kapcsolatot. Ugyanakkor a kiégés mindhárom dimenziója és az átlag alatti rezilencia-pontszám egyértelmű, szignifikáns összefüggésben áll. Többváltozós elemzésünk azt is megmutatta, hogy a reziliencia hiánya - a hagyományos rizikótényezők mellett - fontos prediktor az emocionális kimerülés, a deperszonalizáció és a teljesítménycsökkenés közepes és magas előfordulásában.

A reziliencia és a kiégés összefüggéseinek vizsgálata számos kutatás tárgyául szolgált [24-26]. Vetter és mtsai onkológusok körében folytatott friss, 2018. évi kutatásukban - jelen vizsgálatunk eredményeihez hasonlóan úgy találták, hogy a reziliencia hiánya szoros összefüggést mutat a kiégés magasabb arányával [27]. E vizsgálatok megerősítik azt a feltevést, hogy a munkakörnyezet és a személyiségtényezők kölcsönös egymásra hatásának nagy szerepe van a kiégés alakulásában. Más vizsgálatok is alátámasztják, hogy a reziliencia hiánya vagy alacsony szintje szoros kapcsolatot mutat a pszichés zavarokkal és a maladaptív megküzdési (coping) stratégiákkal [28]. Mindezek az eredmények ismét felhívják a figyelmet az orvosképzés (és -továbbképzés) egyik fontos kérdésére, az önismeret és a stresszkezelő képesség fejlesztésére [29]. Annak okai, hogy egyes gyógyítók reziliensek tudnak maradni, mások pedig a burnout „áldozataivá" válnak, multidimenzionálisak [30]: mind a személyiségtényezők, mind a kollegiális támogatás, mind pedig a munkakörülmények - és ezek interakciói - meghatározó szerepüek lehetnek [31-33]. A kiégésre hajlamosító személyiségtényezők közül a nemzetközi vizsgálatok kiemelik a neuroticizmust, a szorongást és a perfekcionizmust [34-36). Ugyanakkor a vizsgálatok tanúsága szerint a reziliencia a kiégés egyik kulcsmotívuma: a megelőzés és az intervenció mind szervezeti, mind pedig egyéni szinten kiemelt fontosságú $[37,38]$.

Waddimba és mtsai vizsgálatukban úgy találták, hogy a nagyobb rezilienciával jellemezhető orvosok bizonytalanságtűrése magasabb, elégedettebbek a munkájukkal és kollegiális támogatásukkal. Jelen vizsgálatunk eredményeihez hasonlóan, a demográfiai faktoroknak és a munkakörnyezet jellemzőinek nem volt kimutatható hatása a reziliencia alakulására [39].

Vizsgálatunk számos limitációval és erősséggel rendelkezik. Tudomásunk szerint vizsgálatunk az első olyan felmérés, amelyben reprezentatív orvosi mintán, validált mérőeszköz segítségével mutatjuk be a reziliencia mutatóinak alakulását, valamint a reziliencia és a kiégés különböző dimenzióinak összefüggéseit. További fontos erősség, hogy lehetőségünk nyílt mind 2013-ban, mind pedig 2017-ben reprezentatív minta segítségével körüljárni a hazai gyógyítók kiégésének hátterében álló legfontosabb tényezőket. Korlátozó tényező ugyanakkor a viszonylag alacsony válaszadási ráta, ennek hatásait azonban háromdimenziós súlyozással mérsékeltük.

A reziliensebb orvosok betegeinek kedvezóbb a gyógyulási kimenetele, ezen gyógyítók körében a kiégés és a stressztünetek alacsonyabbak $[40,41]$. Az elkövetkező kutatásokban kiemelt figyelmet kell fordítanunk a reziliencia - nemzetközi szakirodalom által jól dokumentált - tényezőire, a társas támogatásra, a pozitív munkahelyi légkörre és a munkavégzés feletti kontroll kérdésére is.

Anyagi támogatás: A 2017-ben folytatott orvoskutatást a Magyar Orvosi Kamara támogatta.

A szerző a cikk végleges változatát elolvasta és jóváhagyta.

Érdekeltségek: A szerzőnek nincsenek érdekeltségei.

\section{Irodalom}

[1] Győrffy Zs, Girasek E. Burnout among Hungarian physicians. Who are the most jeopardized? [Kiégés a magyarországi orvosok körében. Kik a legveszélyeztetettebbek?] Orv Hetil. 2015; 156: 564-570. [Hungarian]

[2] Győrffy Zs, Ádám Sz. Somatic and mental morbidity of young female physicians. Does emotional exhaustion constitute the missing link? [Fiatal orvosnők testi-lelki egészsége. Az emocionális kimerülés a hiányzó láncszem?] Orv Hetil. 2013; 154: 20-27. [Hungarian]

[3] Ádám Sz, Torzsa P, Győrffy Zs, et al. Frequent occurance of level burnout among general practitioners and residents. [Gyakori a magas fokú kiégés a háziorvosok és háziorvosi rezidensek körében.] Orv Hetil. 2009; 150: 317-323. [Hungarian]

[4] Freudenberger HJ. Staff burn-out. J Social Issues 1974; 30: 159-165.

[5] Maslach C. A multidimensional theory of burn-out. In: Cooper CL. (ed.) Theories of organizational stress. Oxford University Press, New York, NY, 1998; pp. 68-85.

[6] Muheim F. Burnout: history of phenomenon. In: Bährer-Kohler S. (ed.) Burnout for Experts. Springer, New York, NY, 2013; pp. 37-46.

[7] Prins JT, van der Heijden FM, Hoekstra-Weebers JE, et al. Burnout, engagement and resident physicians' self-reported errors. Psychol Health Med. 2009; 14: 654-666.

[8] Cimiotti JP, Aiken LH, Sloane DM, et al. Nurse staffing, burnout, and health care-associated infection. Am J Infect Control. 2012; 40: 486-490.

[9] Rosenstein AH. Disruptive and unprofessional behaviors. In: Brower KJ, Riba MB. (eds.) Physician mental-health and wellbeing. Springer, New York, NY, 2017; pp. 61-85.

[10] Vukmir RB. Disruptive healthcare provider behavior: an evidence-based guide. Springer, New York, NY, 2016.

[11] Molnár R, Győrffy Zs. Opportunities for further progress of sociological studies about doctors and medical students. [Az orvo- 
sokkal, orvostanhallgatókkal kapcsolatos vizsgálatok távlatai.] Orv Hetil. 2012; 153: 1738-1744. [Hungarian]

[12] Bringsén A, Andersson HI, Ejlertsson G, et al. Exploring workplace related health resources from a salutogenic perspective. Results from a focus group study among healthcare workers in Sweden. Work 2012; 42: 403-414.

[13] Skarbski Á, Kopp M, Rózsa S, et al. Sense of coherence as an important determinant of mental and physical health. [A koherencia mint a lelki és testi egészség alapvető meghatározója a mai magyar társadalomban.] Mentálhig Pszichoszom. 2004; 5: 7-25. [Hungarian]

[14] Carver CS. Resilience and thriving: issues, models, and linkages. J Soc Issues 1998; 54: 245-266.

[15] Szabó DF. Possibilities of interpretation of resilience: challenges and difficulties. [A reziliencia értelmezésének lehetőségei: kihívások és nehézségek.] Magy Pszichol Szle. 2017; 72: 247-262. [Hungarian]

[16] Masten AS. Ordinary magic: resilience processes in development. Am Psychol. 2001; 56: 227-238.

[17] Cunningham CT, Quan H, Hemmelgarn B, et al. Exploring physician specialist response rates to web-based surveys. BMC Med Res Methodol. 2015; 15: 32

[18] Maslach C, Jackson SE, Leiter M, et al. Maslach Burnout Inventory Manual. Consulting Psychologist Press, Palo Alto, CA, 1996.

[19] Ádám Sz, Mészáros V. Psychometric properties and health correlates of the Hungarian Version of the Maslach Burn-out Inventory - Human Services Survey (MBI-HSS) among physicians. [A humán szolgáltató szektorban dolgozók kiégésének mérésére szolgáló Maslach Kiégés Leltár magyar változatának pszichometriai jellemzői és egészségügyi korrelátumai orvosok körében.] Mentálhig Pszichoszom. 2012; 13: 127-143. [Hungarian]

[20] Connor KM, Davidson JR. Development of a new resilience scale: the Connor-Davidson Resilience Scale (CD-RISC). Depress Anxiety 2003; 18: 76-82.

[21] Járai R, Vajda D, Hargitai R, et al. Characteristics of the 10-item Connor-Davidson Resilience Scale. [A Connor-Davidson Reziliencia Kérdő́ív 10 itemes változatának jellemzői.] Alkalm Pszichol. 2015; 15: 129-136. [Hungarian]

[22] Medscape National Physician Burnout \& Depression Report 2018. Available from: https://www.medscape.com/slideshow/2018-lifestyle-burnout-depression-6009235 [accessed: July 20, 2018]

[23] Robertson HD, Elliott AM, Burton C, et al. Resilience of primary healthcare professionals: a systematic review. Br J Gen Pract. 2016; 66: e423-e433

[24] Choi BS, Kim JS, Lee DW, et al. Factors associated with emotional exhaustion in South Korean nurses: a cross-sectional study. Psychiatry Investig. 2018; 15: 670-676.

[25] Edward KL. The phenomenon of resilience in crisis care mental health clinicians. Int J Ment Health Nurs. 2005; 14: 142-148.

[26] Howard S, Johnson B. Resilient teachers: resisting stress and burnout. Soc Psychol Educ. 2004; 7: 399-420.
[27] Vetter MH, Vetter MK, Fowler J. Resilience, hope and flourish ing are inversely associated with burnout among members of the Society for Gynecologic Oncology. Gynecol Oncol Rep. 2018; 25: 52-55.

[28] Thompson G, McBride RB, Hosford CC, et al. Resilience among medical students: the role of coping style and social support. Teach Learn Med. 2016; 28: 174-182.

[29] Werneburg BL, Jenkins SM, Friend JL, et al. Improving resiliency in healthcare employees. Am J Health Behav. 2018; 42: 39-50.

[30] Taku K. Relationships among perceived psychological growth, resilience and burnout in physicians. Pers Indiv Dif. 2014; 59: $120-123$

[31] Epstein RM, Krasner MS. Physician resilience: what it means, why it matters, and how to promote it. Acad Med. 2013; 88: 301-303.

[32] McCann CM, Beddoe E, McCormick K, et al. Resilience in the health professions. A review of recent literature. Int J Wellbeing 2013; 3: 60-81.

[33] Hu YY, Fix ML, Hevelone ND, et al. Physicians' needs in coping with emotional stressors: the case for peer support. Arch Surg. 2012; 147: 212-217.

[34] Van der Wal RA, Bucx MJ, Hendriks JC, et al. Psychological distress, burnout and personality traits in Dutch anaesthesiologists: a survey. Eur J Anaesthesiol. 2016; 33: 179-186.

[35] Zhou J, Yang Y, Qiu X, et al. Relationship between anxiety and burnout among Chinese physicians: a moderated mediation model. PLoS ONE 2016; 11: e0157013.

[36] Kljajic K, Gaudreau P, Franche V. An investigation of the $2 \times 2$ model of perfectionism with burnout, engagement, self-regulation, and academic burnout. Learn Individ Differ. 2017; 57: 103-113.

[37] Rutter M. Annual research review: resilience - clinical implications. J Child Psychol Psychiatry 2013; 54: 474-487.

[38] Card AJ. Physician burnout: resilience training is only part of the solution. Ann Fam Med. 2018; 16: 267-270.

[39] Waddimba AC, Scribani M, Hasbrouck MA, et al. Resilience among employed physicians and mid-level practitioners in upstate New York. Health Serv Res. 2016; 51: 1706-1734.

[40] Keeton K, Fenner DE, Johnson TR, et al. Predictors of physician career satisfaction, work-life balance, and burnout. Obstet Gynecol. 2007; 109: 949-955.

[41] Cora-Bramble D, Zhang K, Castillo-Page L. Minority faculty members' resilience and academic productivity: are they related? Acad Med. 2010; 85: 1492-1498.

(Győrffy Zsuzsa dr., Budapest, Nagyvárad tér 4., 1089 e-mail: gyorffy.zsuzsanna@med.semmelweis-univ.hu)

A cikk a Creative Commons Attribution 4.0 International License (https://creativecommons.org/licenses/by/4.0/) feltételei szerint publikált Open Access közlemény, melynek szellemében a cikk bármilyen médiumban szabadon felhasználható, megosztható és újraközölhető, feltéve, hogy az eredeti szerzỏ és a közlés helye, illetve a CC License linkje és az esetlegesen végrehajtott módosítások feltüntetésre kerülnek. (SID_1) 